\title{
ABSTRAK \\ LAMA PEREBUSAN TERHADAP KANDUNGAN PROTEIN PADA KERANG DARAH (Anadara granosa)
}

\section{Rosmawati T, Dosen Program Studi Pendidikan Biologi, Fakultas Ilmu Tarbiyah dan Keguruan, IAIN Ambon, 085243144720, E-mail: rosmawati@ rocket.mail.co.id}

Tidak terdapat pengaruh lama perebusan terhadap kadar protein kerang darah (Anadarah granosa) yang di tandai dengan hasil uji F hitung $(2,972)$ lebih kecil dari F tabel $5 \%(5,143)$.

Kata kunci: lama perebusan, Anadarah granosa

\section{ABSTRACT \\ LONG BOILING of PROTEIN CONTENT in the BLOOD COCKLE (Anadara granosa)}

There is no influence of the long boiling of blood clam protein (Anadarah granosa) mark with the F test results count $(2,972)$ smaller than $\mathrm{F}$ table $5 \%$ $(5,143)$.

keyword: long boiling, Anadara granosa

Wilayah Republik Indonesia merupakan salah satu kepulauan di adalah wilayah kelautan yang terletak Indonesia,dengan luas wilayah 181.376 sangat strategis, laut Indonesia selain $\mathrm{km}^{2}$ yang terdiri dari luas lautan dimanfaatkan sebagai sarana perhubungan $527.191 \mathrm{~km}^{2}$, dan luas daratan $54.185 \mathrm{~km}^{2}$, lokal maupun internasional, juga memiliki atau sekitar $90 \%$ merupakan lautan. sumberdaya laut yang sangat kaya dan Dengan wilayah laut yang memiliki luas penting antara lain sumber daya $527.191 \mathrm{~km}^{2}$ (Nybaken, 1988). Provinsi perikanan. Laut juga memiliki arti Maluku sangat kaya akan sumber daya penting bagi kehidupan mahluk hidup hayati laut salah satu diantaranya ikan, seperti manusia,ikan, tumbuh-tumbuhan dan berbagai jenis biota laut lainya. dan biota laut lainya. Provinsi Maluku Seperti kerang darah (Anadara granosa) 
yang sangat diminati oleh masyarakat daerah pesisir, sebagai sumber keperluan pangan.

kerang adalah salah satu jenis bivalvia, dan merupakan sumber protein hewani yang tergolong dalam Complete Protein, karena kadar asam amino essensialnya yang tinggi $(85 \%-95 \%)$ protein yang terkandung didalam kerang jadi mudah dicerna oleh tubuh. Hal ini berarti Kerang bisa dijadikan makanan diet yang tepat untuk mereka yang membutuhkan protein tinggi seperti binaragawan (Anonim, 2012). Kerang darah (Anadara granosa) merupakan salah satu jenis kerang dari kelas Bivalvia yang berpotensi dan memiliki nilai ekonomis untuk dikembangkan sebagai sumber protein dan mineral untuk memenuhi kebutuhan pangan masyarakat Indonesia. Kerang darah biasanya dijadikan makanan dan diproduksi dalam bentuk rebus.

Protein merupakan polimer dari monomer-monomerasam amino yang dihubungkan satu sama lain dengan ikatan peptida. Molekul protein mengandung karbon, hidrogen, oksigen, nitrogen dan kadang kala sulfur serta fosfor. Protein berperan penting dalam struktur dan fungsi semua sel makhluk hidup. Kebanyakan protein merupakan enzim atau subunit enzim. Protein terlibat dalam sistem kekebalan (imun) sebagai antibodi, sistem kendali dalam bentuk hormon, sebagai komponen penyimpanan (dalam biji) dan juga dalam transportasi hara.Sebagai salah satu sumber gizi, protein berperan sebagai sumber asam amino bagi organisme yang tidak mampu membentuk asam amino (Rijal, 2011).

Pada umumnya kerang darah dikomsumsi masyarakat sebagai bahan makanan dengan cara direbus. Lama perebusan diduga dapat berpengaruh terhadap kadar protein ang dimiliki oleh kerang darah, oleh karena itu penulis terdorong untuk melakukan penelitian dengan judul "Pengaruh Lama Perebusan Terhadap Kadar Protein Kerang Darah (Anadara granosa)”.

\section{METODE PENELITIAN}

\section{Jenis Penelitian}

Jenis penelitian ini adalah eksperimental dengan pendekatan eksperimen laboratorium yang bertujuan untuk mengetahui pengaruh lama perebusan terhadap kadar protein kerang darah (Anadara granosa). 


\section{Variabel penelitian}

Variabel dalam penelitian ini adalah lama perebusan kerang darah (Anadara granosa)sebagai variabel.bebas (X). waktu 5 menit, 10 menit, Dan 15 menit. Kadar protein kerang darah (Anadara granosa) sebagai variabel terikat (Y).

\section{Desain penelitian}

Penelitian ini terdiri dari 3 perlakuan, dan tiap perlakuan diulang sebanyak 3 kali, sehingga total pengamatan adalah 9 unit.

\section{Prosedur Penelitian}

a. Mempersiapkan semua alat dan bahan yang akan digunakan.

b. Menyiapkan 90 kerang yaitu 30 individu untuk perlakuan lama pemanasan 5 menit (10 individu untuk ulangan I, II, dan III) 30 individu untuk perlakuan lama pemanasan 10 menit (10 individu untuk ulangan I, II, dan III) dan 30 individu untuk lama pemanasan 15 menit(10 individu untuk ulanag I,II, dan III).

c. Masing-masing perlakuan dari tiaptiap ulangan ditimbang sebanyak 10 g. dan dihaluskan. d. Setelah dihaluskan sampel ditimbang kembali sebanyak 0,5 g. kemudian dimasukkan ke dalam labu kjdal.

e. Tambahkan $2 \mathrm{~g}$ campuran selen dan $25 \mathrm{ml} \mathrm{H}_{2} \mathrm{SO}_{4}$ pekat.

f. Panaskan di atas pemanas listrik atau api pembakaran. sampai mendidih.

g. Biarkan sampai dingin, kemudian encerkan dan masukan ke dalam labu ukur $100 \mathrm{ml}$.

h. Pipet $5 \mathrm{ml}$ larutan dan masukan ke dalam alat penyuling.

i. Sulingkan selama kurang lebih 10 menit, kemudian tambahkan $10 \mathrm{ml}$ larutan asam borat $2 \%$.

j. Titrasikan dengan menggunakan $\mathrm{HCl}$ $0,01 \mathrm{~N}$.

\section{Teknik Pengumpulan Data}

Data berupa kadar protein kerang darah diperoleh melalui perhitungan dari absorbansi masing-masing sampel yang diukur dengan menggunakan perangkat alat mikrojedal.

\section{Teknik Analisis Data}

Data yang terkumpul dari hasil pengukuran dianalisis dengan mengunakan uji analisis varian pada taraf signifikan $5 \%$ jika ada pengaruh maka dianjurkan dengan uji BNT. 


\section{HASIL PENELTIAN}

Tabel 1 Hasil Penelitian pengaruh lama perebusan terhadap kadar protein kerang darah

\begin{tabular}{|c|c|c|c|c|c|}
\hline \multirow{2}{*}{ Perlakuan } & \multicolumn{3}{|c|}{ Ulangan (\%) } & \multirow{2}{*}{ Jumlah (\%) } & \multirow{2}{*}{ Rata-rata (\%) } \\
\cline { 2 - 4 } & 1 & 2 & 3 & & 0,1 \\
\hline 5 menit & 0,010 & 0,010 & 0,010 & 0,030 & 0,007 \\
\hline 10 menit & 0,008 & 0,007 & 0,007 & 0,022 & 0,004 \\
\hline 15 menit & 0,004 & 0.004 & 0,004 & 0,012 & \\
\hline
\end{tabular}

Tabel 1 memperlihatkan bahwa pada kadar protein yaitu pada lama perebusan perlakuan 5 menit, 10 menit, dan 15 menit 15 menit dan yang paling sedikit telah terjadi penurunan kadar protein yaitu mengalami penurunan kadar protein yaitu menjadi sebesar 0,1\%, 0,007\% dan 0,004 lama perebusan 5 menit karena kandungan $\%$. Pada ke tiga perlakuan di atas yang proten yang ada yaitu $0,1 \%$. paling banyak mengalami penurunan

Tabel 2 Hasil Uji Anava Pada Kerang Darah

\begin{tabular}{|c|c|c|c|c|c|}
\hline Sumber keragaman & DB & JK & KT & F hitung & $\begin{array}{c}\text { F tabel 5 } \\
\%\end{array}$ \\
\hline Perlakauan & 2 & 0,039 & 0,165 & 2,972 & 5,143 \\
\hline Galat & 6 & 0,291 & 0,0485 & & \\
\hline Total & 8 & 0,218 & - & & \\
\hline
\end{tabular}

Dari tabel 2 tentang hasil uji anava terlihat bahwa tidak ada pengaruh lama perebusan terhadap kadar protein kerang darah (Anadara granosa) yang ditandai dengan F hitung $(2,972)$ lebih kecil dari F tabel $5 \%(5,143)$.

\section{PEMBAHASAN}

Dari tabel 4.1 terlihat bahwa ada pengaruh lama perebusan terhadap kadar protein kerang darah, hal ini dapat terjadi karena semakin lama waktu perebusan mengakibatkan semakin turun kadar protein yang dimiliki oleh kerang darah,dikatakan demikian karena pada suhu yang tinggi terjadi kerusakan protein/denaturasi. Kerang darah merupakan sumber protein hewani yang tergolong dalam Complete Protein, karena kadar asam amino essensialnya yang tinggi $(85 \%$ - 95\%) protein yang terkandung didalam kerang darah jadi mudah dicerna oleh tubuh, namun dikarenakan semakin lama waktu perebusan, akan semakin banyak protein yang rusak (Anonim, 2012). 
Protein merupakan gabungan asamasam amino dengan cara ikatan peptida, yaitu ikatan antara gugus amino. Protein disusun oleh 22 macam asam amino,tetapi dari keseluruhan itu yang berfungsi sebagai penyusun utama protein hanyalah 20 macam. Proses metabolism protein didahului dengan proses katabolisme (penguraian) protein menjadi asam amino, tahap tersebut meliputi proses pembukaan (inisiasi), perpanjangan (elongasi), dan perakhiran (terminasi). Proses sintesis protein melibatkan asam amino. Bila sel memerlukan protein, maka akan terjadi rangkaian aktifitas. Dari rangkaian tersebut selanjutnya akan menyebabkan asam-asam amino saling berkaitan membentuk peptida.

Metabolism protein tidak secara langsung terlibat dalam memproduksi energi. Tetapi metabolism protein terlibat dalam produksi enzim, hormon, komponen struktual, dan protein darah dari sel-sel badan dan jaringan metabolisme energi yang berasal dari protein didahului dengan degradasi protein menjadi asam-asam amino. Kemudian asam-asam amino dilepaskan gugus aminonya melalui deaminasi oksidatif di sel-sel hati. Hasil deaminasi akan masuk dalam siklus krebs guna membentuk energi.

Protein berbentuk serat (fibrous), salah satunya adalah: kolagen merupakan protein utama pada jaringan penghubung skeletal. Umumnya collagen tidak larut dalam air dan tahan pada enzim pencernaan hewan, tetapi berubah cepat dalam bentuk larutan, dalam bentuk gelatin lebih mudah dicerna apabila dipanaskan dalam air atau larutan asam basa (anonym, 2012)

Lama perebusan dapat mengurangi kadar protein pada kerang darah (Anadara granosa) karena proses perebusan yang terlalu lama dapat menghancurkan protein yang dimiliki oleh kerang darah sehingga dapat mengurangi kadar protein pada kerang darah. Denaturasi protein terjadi bila susunan ruang atau rantai polipeptida suatu molekul protein berubah. Sebagian besar protein globuer mudah mengalami denaturasi. Jika ikatan-ikatan yang membentuk konfigurasi molekul tersebut rusak, molekul akan mengembang. Ada dua macam denaturasi, pengembangan polipeptida dan pemecahan protein menjadi unit yang lebih kecil tanpa disertai pengembangan molekul. Terjadinya kedua jenis denaturasi ini 
tergantung pada keadaan molekul. Yang terjadi pada rantai polipeptida, Ikatanikatan yang dipengaruhi oleh proses denaturasi ini adalah ikatan hidrogen, ikatan hidrofobik dan ikatan (Rijal, 2011).

\section{KESIMPULAN}

Berdasarkan hasil penelitian di atas, penulis dapat mengambil kesimpulan bahwa: Tidak terdapat pengaruh lama perebusan terhadap kadar protein kerang darah (Anadarah granosa) yang di tandai dengan hasil uji $\mathrm{F}$ hitung $(2,972)$ lebih kecil dari F tabel $5 \%(5,143)$.

\section{SARAN}

1. Berdasarkan atas hasil dan penelitian yang telah dilakukan, maka disarankan: Agar masyarakat yang ingin mengkomsumsi kerang darah, waktu yang digunakan untuk proses perebusan tidak terlalu lama, agar kandungan proteinya tidak berkurang.

2. Perlu adanya penelitian lanjutan yang terkait dengan lama perebusan 5 menit untuk pengujian kandungan bakteri yang terkandung pada kerang darah.

DAFTAR PUSTAKA

Anonim Arti kata
http://www.artikata.com/arti- 150323-rebus.html (diakses pada hari rabu 25 Januari 2012)

Anonim

$$
\text { Arti }
$$
kata

http://www.artikata.com/arti145212-protein.html (diakses pada hari rabu 25 Januari 2012)

Anonim

$$
\text { Artikel. }
$$
http:// www.answer.com/topik/sipuncul c-1 (di akses pada 04/januari/2012)

Anonim Kerang http://id.wikipedia.org/wiki/Kera ng (diakses pada 25 Januari 2012)

Anonim

$$
\text { "Kerang" }
$$

http://bangfirman.multiply.com/j ournal/item/4?\&show_interstitial $=1 \& \mathrm{u}=\% 2$ Fjournal\%2Fitem (diak ses pada hari rabu 12 Januari 2012)

Anonim Kerang darah (http://richocean.wordpress.com/f auna-lain/kerang/ Di akses pada hari rabu/25/01/2012

Anonim "Kerang darah" http://repository.usu.ac.id/bitstrea $\mathrm{m} / 123456789 / 20725 / 4 /$ Chapter\% 20II.pdf (diakses pada hari rabu 11 Januari 2012)

Anonim Manfaat Kerang Darah (http ://djarul26creend.webnode.com/n ews/manfaat-kerang/. di akses pada hari senin tanggal 12/032012)

Anonim Morfologi kerang http://marinamoy.blogspot.com/2 $\underline{011 / 04 / \text { karakteristik-dan- }}$ morfologi-kerang.html (diakses pada hari rabu 12 Januari 2012)

Anonim,

"Protein" (http://id.wikipedia.org/wiki/Prot ein. diakses pada 04/januari/2012). 
Anonim "Pengaruh Waktu Dan Jenis Wadah Pemasakan Terhadap Komponen MakananDalamGudeg"(http://11 $\underline{\text { 8.96.137.181:880/bahanajar/dow }}$ nload/ebooks_kimia/makalah/Pen garuh\%20Pada\%20Gudeg.pdf, diakses pada kamis 4 Oktober 2012)

Badan pusat statistik provinsi Maluku. 2003 hlm 3

Rijal Muhama. 2011. Biokima Dasar. IAIN Ambon.

Nybaken, biologi laut.Suatu pendekatan ekologis. 1988. Jakarta 